\title{
PROFESSIONAL PLACEMENT SERVICE 1996 ANNUAL MEETING
}

APSA will sponsor a Professional Placement Service at the Hotel Nikko, during the 1996 Annual Meeting in San Francisco, California. The Placement Service will be open from 8:00 a.m. to 6:00 p.m., Thursday, August 29 through Saturday, August 30; and from 9:00 a.m. to Noon, Sunday, September 1.

Facilities will be available to review job listings and resumes, exchange messages, and conduct interviews. To register for the Placement Service and obtain Employer Forms (Job Orders) or Application (Candidate) Forms, please complete and mail the form below as soon as possible, but no later than July 26, 1996. Employer and/or Candidate forms will be forwarded to you upon receipt of your request.

CANDIDATES WHO DO NOT REGISTER FOR THE PLACEMENT SERVICE BEFORE THE MEETING WILL BE CHARGED \$10.00 TO REGISTER AT THE MEETING. Employers whose Departments are not members of the APSA Departmental Services Program will be charged a Placement Service Fee of $\$ 100.00$ (PREPAID). All persons using the Placement Service are required to register for the 1996 Annual Meeting. Badges must be worn for admittance to the Professional Placement Service.

PLACEMENT SERVICE PRE-REGISTRATION IS STRONGLY RECOMMENDED.

Please RUSH me the forms I have checked below!

Name:

Mailing Address:

City: State: Zip:

Organization or Department:

Candidate $\square$ Employer---Number of Positions

Mail to:

1996 Annual Meeting Professional Placement Service

American Political Science Association

1527 New Hampshire Avenue, N.W.

Washington, D.C. 20036 